\title{
Kimberlite magmatism in Finland: Distinct sources and links to the breakup of Rodinia
}

\author{
HAYDEN DALTON ${ }^{1 *}$, ANDREA GIULIANI ${ }^{1,2}$, DAVID \\ PHILLIPS ${ }^{1}$, JANET HERGT ${ }^{1}$, ROLAND MAAS ${ }^{1}$, JON \\ WOODHEAD $^{1}$, ERIN MATCHAN ${ }^{1}$, HUGH O'BRIEN $^{3}$. \\ ${ }^{1}$ Kimberlites and Diamonds (KiDs), School of Earth \\ Sciences, The University of Melbourne, Australia. \\ ${ }^{2}$ Institute of Geochemistry and Petrology, Department of \\ Earth Sciences, ETH Zurich, Switzerland \\ ${ }^{3}$ Geological Survey of Finland (GTK), Espoo, Finland. \\ *correspondence: haydend@student.unimelb.edu.au
}

The Karelian Craton in Finland is host to (at least) two distinct pulses of kimberlite magmatism. Twenty kimberlite occurrences have so far been discovered on the southwest margin of the craton at Kaavi-Kuopio and seven kimberlites are located in the Kuusamo area within the core of the craton.

Comprehensive radiometric age determinations (U- $\mathrm{Pb}, \mathrm{Ar}-$ $\mathrm{Ar}$ and $\mathrm{Rb}-\mathrm{Sr}$ ) reveal that all kimberlite activity was restricted to the Proterozoic. The Kaavi-Kuopio field was emplaced over a protracted period from $\sim 610$ to $550 \mathrm{Ma}$ and is predated by the Kuusamo cluster that represents a relatively short pulse of magmatism at $\sim 750$ to $730 \mathrm{Ma}$. The emplacement of kimberlites globally has recently been linked to supercontinent reorganisation and we propose a similar scenario for these Finnish occurrences which, at the time of kimberlite emplacement, were situated on the Baltica paleo-continent. This land mass was contiguous with Laurentia in the Proterozoic and together formed part of Rodinia. The breakup of Rodinia is considered to have commenced at $\sim 750 \mathrm{Ma}$ and initiation of the opening of the Iapetus ocean at $\sim 615 \mathrm{Ma}$. Contemporaneous with Kaavi-Kuopio magmatism, this latter period of Neoproterozoic crustal extension also includes the emplacement of kimberlites and related rocks in areas that were linked with Baltica as part of Rodinia - West Greenland and eastern North America. Both the initial and final periods of Rodinia's breakup have been linked to mantle upwellings from the core-mantle boundary. We suggest that kimberlite magmatism in Finland was promoted by the influx of heat from mantle upwellings and lithospheric extension associated with the demise of Rodinia.

Although both magmatic episodes are potentially linked to the breakup of Rodinia, whole-rock and perovskite radiogenic isotope compositions for the Kuusamo kimberlites $\left(\varepsilon \mathrm{Nd}_{(\mathrm{i})}+2.6\right.$ to $+3.3, \varepsilon \mathrm{Hf}_{(\mathrm{i})}+3.1$ to +5.6$)$ are distinct from the Kaavi-Kuopio kimberlites $\left(\varepsilon \mathrm{Nd}_{(\mathrm{i})}-0.7\right.$ to $+1.8, \varepsilon_{\mathrm{Hf}}(\mathrm{i})-6.1$ to +5.2$)$. The spread in Hf isotope compositions for the Kaavi-Kuopio magmas may be linked to variable assimilation of diverse mantle lithologies. 